\title{
Religion and ethno-nationalism: Turkey's Kurdish issue
}

\author{
ZEKI SARIGIL and OMER FAZLIOGLU \\ Department of Political Science, Bilkent University, Ankara, Turkey
}

\begin{abstract}
One approach within the Islamic camp treats Islam, which emphasizes overarching notions such as the 'Islamic brotherhood' and 'ummah', as incompatible with ethno-nationalist ideas and movements. It is, however, striking that in the last decades, several Islamic and conservative groups in Turkey have paid increasing attention to the Kurdish issue, supporting their ethnic demands and sentiments. Even more striking, the leftist, secular Kurdish ethno-nationalists have adopted a more welcoming attitude toward Islam. How can we explain such intriguing developments and shifts? Using original data derived from several elite interviews and a public opinion survey, this study shows that the struggle for Kurdish popular support and legitimacy has encouraged political elites from both camps to enrich their ideological toolbox by borrowing ideas and discourses from each other. Further, Turkish and Kurdish nationalists alike utilize Islamic discourses and ideas to legitimize their competing nationalist claims. Exploring such issues, the study also provides theoretical and policy implications.
\end{abstract}

KEYWORDS: Islamic brotherhood, Kurdish ethno-nationalism, Kurdish issue, Turkish nationalism

\section{Introduction}

Several scholars observe that Islam plays an important role in Kurdish society in Turkey (e.g. see Bruinessen 1992, 2000; McDowall 1992: 17). The role of religion in Kurdish ethno-politics or ethno-nationalism, however, has received scant attention. ${ }^{1}$ This subject deserves greater consideration because of the striking developments in the last few decades. As Islamic thought emphasizes overarching ideas and identities such as the 'Islamic brotherhood' and 'ummah' (the worldwide community of Muslim believers), rather than ethnic or national particularities, several conservative circles consider Islam incongruent with ethno-nationalist ideas and movements. However, certain Islamic groups and circles in Turkey are paying increasing attention to the Kurdish cause, supporting ethnic demands and sentiments. Some have gradually embraced an ethno-nationalist discourse and attitude, thus acquiring an ethno-religious outlook. Even more striking, left-oriented, secular Kurdish groups (e.g. pro-Kurdish ethnic parties and the Kurdistan Workers' Party, Partiya Karkeren Kurdistan, PKK), who were formerly distanced from 
religion, have adopted an increasingly positive and welcoming attitude toward Islam in the last decades. As a result, religious sentiments, rights and freedoms have become part of the political discourse and strategy of the Kurdish ethnonationalist movement, especially since the early 2000s. This study broaches the following questions: How can we explain such intriguing developments and shifts? What are the implications for broader theoretical debate on ethno-nationalism?

\section{Arguments}

Using original data derived from several semi-structured elite interviews ${ }^{2}$ and public opinion survey data, ${ }^{3}$ this study shows that the struggle to enhance their legitimacy and popularity in Kurdish society has encouraged Islamist and secular camps to enrich their ideological toolbox by borrowing ideas and discourses from each other. Thus, the religious side has begun to pay greater attention to the Kurdish cause and Kurds' rights and freedoms, while the secular Kurdish ethno-nationalist movement has embraced Islamic sentiments and religious rights and freedoms. It is interesting that Turkish and Kurdish nationalists alike utilize religious discourses and ideas to legitimize their competing nationalist claims. Put differently, Islam is employed for contradictory purposes: to promote Kurdish political and cultural rights by pro-Kurdish groups and to constrain or rebuff Kurdish nationalist claims and demands by Turkish nationalists and Islamists. Instrumentalist usage of Islam by competing nationalisms, however, has increased friction and tension between Kurdish ethno-nationalists and circles subscribing to Turkish-Islamic understanding (e.g. the ruling conservative Justice and Development Party, Adalet ve Kalkınma Partisi, AKP). Regarding policy and theory implications, the findings suggest that promoting Islam as an antidote to ethno-nationalism is not realistic. With respect to theoretical ramifications, it will be shown that this particular case has some major implications for the elite perspective, which draws attention to the role of political elites in ethno-nationalist processes.

The article proceeds inductively as follows: The next section deals with the diverse positions within Islamic circles vis-à-vis Kurdish ethno-nationalism. Following, we discuss the attitude of the Kurdish ethno-nationalist movement toward Islam, focusing on the adoption of a more positive approach toward religion by secular Kurdish ethno-nationalists in recent decades. This section also examines the conservative government's reaction to this change. In the final section, we present our conclusions and discuss some policy and theory implications.

\section{Islamic circles and Kurdish ethno-nationalism}

Regarding the nexus between Islam and ethno-nationalism, we see two contrasting orientations or approaches in Islamic circles. One approach treats Islam and ethno-nationalism as mutually exclusive. For instance, Vatikiotis (1987:10-1) observes:

(C) The author(s) 2013. Nations and Nationalism (C) ASEN/John Wiley \& Sons Ltd 2013 
... Islam rejects common national barriers, based on territorial frontiers, and ethniclinguistic and racial differences ... Unlike earlier religions, Islam did not stop at the call to the faith. It proceeded to the establishment of a state which embodied a new nation, that of the believers, or the faithful: ummat al-mu'minin. The very basis of this new nation and its nationalism, if you wish, has been the religion of Islam . . . Islam, in other words, is integrative or has integrative ambitions on a universal scale.

The nation state in Islam is then an ideological, not a territorial concept. It comprises the community of the faithful or believers wherever they may be.

As Ataman (2003: 90) also observes, according to the Islamic theory of ethnicity, all Muslim ethnic groups are considered as one nation or one political entity: ummah (a transnational, Islamic community). Thus, nationalist ideologies or movements are considered divisive because Islam emphasizes the unity of God and the unity of ummah (al-Ghannouchi in Ataman 2003: 91). Nevertheless, Islamic thought does not ignore or reject different cultures, languages or nationalities; it ultimately acknowledges that ummah is made up of many different people speaking different languages. However, for Islamic understanding, the primary loyalty should belong to the ummah rather than to nationality or the nation-state.

In the context of the Kurdish issue, then, various Islamist writers and intellectuals disapprove of ethno-nationalist ideas and projects. For instance, Sakallioglu (1998: 81) observes that for Islamists, "a "national solution" for the Kurdish problem in the Middle East goes against the core principles of the ummah because setting up nation-states divides the Muslim communities in the region' (see also Bruinessen 2000: 57). ${ }^{4}$ Likewise, Houston (2001: 157) notes that:

... Islamist discourse on the Kurdish problem gives its assent to the existence and equality of Kurds as a kavim (people/nation) and to Kurdish as a language, but calls for the subordination of such an identity to an Islamic one ... Islamist discourse stakes a claim to be an ethnically neutral political actor: in the new social contract posited by Islamism, ethnic irons are withdrawn from the fire in the name of a more universalistic identity [ummah].

In party politics, we see that pro-Islamic political actors also emphasize the Islamic brotherhood, especially the pro-Islamic National Outlook Movement (Milli Görüş Hareketi, MGH), which emerged onto the Turkish political scene in the early 1970s and was led by Necmettin Erbakan (1926-2011) (see also Duran 1998: 114). The pro-Islamic movement regards Islamic identity and consciousness as the major shared identity among Turkish citizens, transcending ethnic consciousness and particularities (Yavuz 1997: 65-6). It is believed, however, that diverse ethnic identities can coexist peacefully within an Islamic framework. For instance, Mustafa Kamalak, leader of the Felicity Party (Saadet Partisi, SP), currently representing the MGH in the Turkish party system, ${ }^{5}$ stated to the authors:

We believe that in order to solve the [Kurdish] problem, we should first disregard national or racial ideas and notions. Instead, we should focus on unifying concepts and 
common values between the Kurds and Turks. That would be Islam. Rather than race, Islam is the shared value between the Kurds and Turks and we should keep it as powerful and alive ... Any proposal or initiative excluding or ignoring Islam and Islamic sentiments would not have much chance to solve the problem. ${ }^{6}$

The second approach regarding Islam and ethno-nationalism sees no tension or conflict between the two. It assumes that they can coexist peacefully. Several conservative Kurdish groups have developed an ethno-nationalist discourse and attitude in the recent decades. A telling example is the Kurdish Hezbollah (the Party of God, KH), a militant Kurdish-Islamist organization influenced by Iran (see Yavuz and Ozcan 2006: 107). In the 1990s, the KH engaged in armed conflict with the PKK, which the KH feels is an atheist and Marxist organization. The $\mathrm{KH}$ also targeted several secular, leftist Kurdish activists (McDowall 1996: 432). It is widely believed that the state protected and supported the KH in its armed efforts (see Bruinessen 2000: 55; McDowall 1996: 433; Sakallioglu 1998: 78; Yavuz 2001: 14; Yavuz and Ozcan 2006). In 2000, however, the state began targeting the KH. Founder Huseyin Velioglu was killed during a police raid in Beykoz, Istanbul, while other leading members such as Edip Gumus and Cemal Tutar were arrested. In the following period, thousands of $\mathrm{KH}$ members were detained.

After experiencing the state's crackdown, the $\mathrm{KH}$ renounced violence and laid down its arms in the early 2000s. Since then, it has focused on strengthening its social base among the Kurds. For instance, in 2004, sympathizers of the KH established an Islamic charity association called Mustazaf-Der (the Association of Solidarity with the Disadvantaged), based in Diyarbakir. Nuri Guler, chairperson of Mustazaf-Der's Diyarbakir branch, stated to the authors that the association approaches the Kurdish issue from an Islamic point of view. Interestingly, however, Guler expressed similar issues to the secular Kurdish ethno-nationalists, arguing that the primary source of Turkey's Kurdish problem is the state's denial and suppression of Kurds and their basic rights and freedoms. According to Guler, the Turkish state has tried to assimilate Kurds by banning the Kurdish language and identity. Guler continued, stating:

As an Islamic organization, we believe that every nation or race should live its own culture and language freely . . . In the Ottoman period, this region used to be known as Kurdistan. Furthermore, Kurdish education was the common practice in madrasas. Thus, today we should reinstall Kurdish education in Kurdistan . . . Islam does allow it. Although the language of the Koran is Arabic, Islam does not really suppress any language or culture.

Huseyin Yilmaz, chairperson of Mustazaf-Der, expressed similar views:

The Kurds should gain official recognition and status. The state should adopt a policy of affirmative action vis-à-vis the Kurds, who have been disadvantaged by the Turkish state. Kurdish language should be taught in schools as an elective course. Following that, it should be recognized as an official language. Public service should be provided 
in Kurdish in the region. In addition, the Directorate of Religious Affairs should initiate Kurdish sermons during Friday prayers. ${ }^{8}$

Yilmaz also stated that Mustazaf-Der is sympathetic to the idea of establishing an Islamic and pro-Kurdish political party to challenge the ruling, conservative AKP and the secular, ethno-nationalist Peace and Democracy Party (Barıs ve Demokrasi Partisi, BDP) ${ }^{9}$ in the southeast. Indeed, in spring 2012, religious Kurdish groups, led by Sitki Zilan, a conservative, Kurdish lawyer from Diyarbakir, initiated preparations for a pro-Islamic and pro-Kurdish political party. ${ }^{10}$ Thus, despite its radical Islamic identity, Mustazaf-Der's standing on the Kurdish issue has major similarities with the ethno-nationalist position.

Similar pro-Kurdish discourses and attitudes exist among other Islamic circles in the region. The pro-Islamic Zehra Group, organized around the Zehra Foundation and Zehra-Der, is an interesting case. Constituting the pro-Kurdish wing of the conservative Nur movement, ${ }^{11}$ the Zehra Group has positioned itself against the pro-state and pro-Turkish wing (i.e. the Gulen community $)^{12}$ and embraced the mission of promoting Kurdish language and culture (see also Bruinessen 2000: 56). For instance, since 1992, the group has published the Kurdish Islamic journal Nûbihar (Spring), focusing on cultural and literary issues. Muhittin Kaya from the journal asserted:

Certain conservative circles emphasize the notion of 'the Islamic brotherhood' as a solution for the Kurdish problem. Actually, by using religion they try to undermine the legitimacy of Kurdish demands. This is not really sustainable. On one hand, you regard the Kurds as your brothers but on the other hand, you ignore their language and cultural rights. If a Turk enjoys certain language and cultural rights in this country, a Kurd should also enjoy the same rights and freedoms. As Prophet Muhammed also states, as brothers, Muslims should not oppress each other. Thus, rather than Islamic brotherhood, legal brotherhood and equality would be the real solution to the problem. ${ }^{13}$

As evident from this statement, conservative Kurdish activists are critical of the idea of the Islamic brotherhood, which is used by certain pro-Islamic circles to promote unity and solidarity among Kurds and Turks. Because the Islamic brotherhood subsumes ethnic identities under an Islamic identity, religious Kurdish activists regard it as assimilationist. More striking, Kaya is also drawing upon religious ideas to promote the Kurdish cause.

Since the early 1990s, religious Kurds have become more interested in Kurdish history, language, culture and rights, ${ }^{14}$ and their pro-Kurdish discourse is empowered by frequent references to Islam and the Koran. In other words, conservative Kurdish circles utilize religious discourse to legitimize ethnic differences and demands and to defend Kurds against assimilation. They emphasize that Allah created different races and languages equally. If one agrees with this interpretation, then suppressing the language and rights of the Kurdish people violates the teachings of the Koran. In his analysis of Kurdish Islamists' position on the Kurdish issue, Houston (2001: 177) suggests that the 'Kurdish Islamist discourse is concerned to show that on the contrary 
Islam does not cancel ethnic subjectivity and that such subjectivity is not a Western innovation... At a more basic level, Allah delights in diversity, otherwise humanity would have all been created the same'.

As will be discussed in the following, the Kurdish ethno-nationalist movement has also undergone a major change in the last few decades, developing a more cordial view of religion (see also Bruinessen 2000: 57). The following section analyses the attitude of the secular, leftist Kurdish movement toward religion in the last decades.

\section{Islam and the secular, leftist Kurdish movement}

As a secular insurgent movement, the PKK originated from the revolutionary left in Turkey in the late 1970s (see also Jongerden and Akkaya 2011; Ozcan 1999; Taspinar 2005; Yavuz 2001: 9-10). In its early years, the PKK aimed at establishing a united Kurdistan based on Marxist-Leninist principles. By the early 1990s, however, the PKK started to distance itself from those ideas and became increasingly ethno-nationalist, emphasizing Kurdish rights and freedoms (Yavuz 2001). ${ }^{15}$ In parallel to such an ideological shift, it softened its attitude toward religion (Bruinessen 2000; Houston 2001: 185; White 2000: 48). Bruinessen (2000: 54-5), a prominent scholar of Kurdish studies, notes:

It was only with the demise of Marxism as a political force that Islam returned to Kurdish politics as a significant factor and Kurdish identity politics to Islamism ... The PKK adopted a more respectful attitude towards Islam. It had initially, like all left-wing movements in Turkey, been not only secularist but distinctly anti-religious.

As a result, in the early 1990s, the PKK formed an Islamic, Kurdish nationalist group called the Islamic Party of Kurdistan (Partiya Islami Kurdistan) (McDowall 1996: 433). It also developed close relations with meles (Kurdish for mullahs; see the following) and tried to organize them around Kurdish nationalism. ${ }^{16}$ By the 2000s, we see that religious rights and freedoms had become a natural part of the political discourse and strategy of Kurdish ethno-nationalists. The PKK's approach toward religion in its first period saw Islam as an obstacle to the development of national consciousness and modernity among Kurds. Therefore, the return of religion or at least a much more conciliatory attitude toward it constitutes a turning point in the Kurdish ethno-nationalist movement.

The pro-Kurdish BDP has been even more active in utilizing a pro-religion discourse and political strategy. For instance, on 25 March 2011, as part of a larger sivil itaatsizlik (civil disobedience) campaign, the BDP initiated Sivil Cuma 'Civilian Friday Prayer', which boycotts Friday prayers at statecontrolled mosques. Party officials argue that they do not want to stand behind state-appointed imams because they feel that state imams propagate pro-state, pro-government views and Turkishness. Party co-leader Selahattin Demirtas claims: 
Imams are selected by the National Security Council and then sent here [the southeast]. We ask our people not to pray behind those imams who are sent here with a special mission ... We know that there are state imams working for the Justice and Development Party in the region. ${ }^{17}$

The party leadership thus organized prayers, led by meles, who volunteer for the events outside mosques, at public squares. Meles are Kurdish religious scholars and teachers, highly respected by the people in the region. Most of them have received 'unofficial' madrasa education and training. ${ }^{18}$ Thus, they are also regarded as non-state imams. The meles leading the prayers deliver the sermons in Kurdish and they make highly ethno-nationalist statements. ${ }^{19}$ For instance, during one of the Civil Friday Prayers in Cizre, a district of Sirnak, Mele Sait Acartay criticized the Directorate of Religious Affairs (known as Diyanet, see the following) and stated in Kurdish, 'Is there any language ban in religion? Can you show us whether the Quran has a language ban? They say we are brothers ... However, one brother's language is permitted [Turkish], while the other's is banned. What kind of a brotherhood is this?' ${ }^{20}$ The Civilian Friday Prayers have emerged as a major challenge to Turkish-Islamic understanding and the state's control over religion. As will be discussed in the following, pro-Turkish, conservative circles openly criticize this initiative.

The BDP also organized a commemoration ceremony for Sheikh Said on 29 June 2011, the anniversary of his execution. Said was a Kurd from the Naqshbandi order and led the first major Kurdish rebellion against the newly established, secular Turkish Republic in early 1925. The rebellion incorporated ethno-nationalist and religious motivations and goals (Entessar 1992: 84; Jwaideh 2006: 209-10; Yavuz 2001: 8). Said was captured by Turkish security forces in mid-April and hanged with most of the other rebel leaders at Dagkapi Square in Diyarbakir. During the commemoration ceremony, participants cited verses from the Koran and prayed for him. Having died for Kurdish rights and freedoms, he is also referred to as a martyr. ${ }^{21}$ Kurdish Islamic civil society organizations also participated in the commemoration.

In line with its new approach toward religion and religious issues, the BDP also supported popular (and subsequently elected) candidates from the conservative Kurdish movement, such as Altan Tan and Serafettin Elci, during the June 2011 elections. Tan, who was a prominent figure in Turkey's pro-Islamic movement (i.e. the National Outlook Movement), is now active in Kurdish ethno-politics, promoting pro-Islamic and pro-Kurdish ideas. Criticizing the conservative government's attitude on the Kurdish issue, Tan has stated, 'This government resorts to religion whenever it is in trouble and abuses religion for political interests . . . If Prime Minister Erdogan is a real devout Muslim, then, let's resort to Sharia [Islamic law] and see what rights and freedoms it grants to the Kurds ...'22 After the June 2011 elections, the BDP leadership put forth a bill proposing that female deputies should be allowed to wear headscarves during parliamentary meetings. ${ }^{23}$ This action surprised many circles because it has been conservative parties rather than secular parties that have been fighting headscarf bans. 
In addition to such actions and initiatives, we see Kurdish ethnonationalists increasingly using Islamic ideas and references. For instance, to legitimize the existence of ethnic and linguistic differences and their equality in front of God, Kurdish activists frequently cite verses from the Koran, especially the thirteenth verse of chapter 49 (Al-Hujraat): 'O mankind! We have created you from a male and a female and have made you into nations and tribes that you may know each other. Surely the noblest among you in the sight of Allah is the most godfearing of you. God is All-knowing, All-aware'. The twenty-second verse of chapter 30 (Rum) is also highly quoted: 'And of His signs is the creation of the heavens and earth and the variety of your tongues and hues. Surely in that are signs for all living beings' ${ }^{24}$ Kurdish ethno-nationalists argue that if all languages and races are created equal by God, then the denial and suppression of the Kurdish language and Kurdish rights violates God's word. For instance, referring to Al-Hujraat, Mele Zahit Çiftkuran, chairperson of the Association for the Solidarity of Imams (DIAYDER), ${ }^{25}$ which is sympathetic to the BDP, stated to the authors:

They tell us that we are religious brothers but they use the Islamic brotherhood to suppress and silence Kurdish demands ... When we look at the Koran, we see that Allah created different races and languages equally. One is definitely not superior to another ... We are, however, unequal brothers. Diyanet, for instance, does not really represent all religious sects. It takes side with the Sunni-Hanefi school. ${ }^{26}$

Similarly, Mele Mehmet Gönden, a member of the Diyarbakir-Sur municipal assembly, asserted:

If we look at the Koran, we see that Allah created different races and languages equally. Allah does not distinguish among them ... If so, then how can you ignore or suppress a nation and its language . . If you do that, then, you would violate the Koran. ${ }^{27}$

The previous examples are enough to conclude that we are seeing a major change in Kurdish ethno-nationalists' attitude about religion. The movement, which had ignored religion in its earlier stages, has developed a more positive approach toward Islam and the men of religion (e.g. local mullahs) in the 1990s. In the 2000s, we saw increasing usage of Islam by Kurdish elites to legitimize ethno-nationalist messages. As a result of these changes, the secularist bias of the Kurdish ethno-nationalist movement is decreasing. As Gulten Kisanak, co-leader of the BDP, stated 'In the BDP, we are open to both secular and religious individuals ... During Ramadan, we continue serving teas or coffees to our guests in party buildings but we also organize iftar dinners [the dinner eaten by Muslims to end their fast after sunset every day during Ramadan] for those who fast' ${ }^{28}$

How do we explain the timing of this shift by Kurdish ethno-nationalists? In other words, why have Kurdish ethno-nationalists' pro-Islamic discourses and attitudes become more visible in the last decade? Figure 1, which shows the electoral popularity of major political orientations in the Kurdish provinces, provides an answer to this question. We see that in the last two decades, 


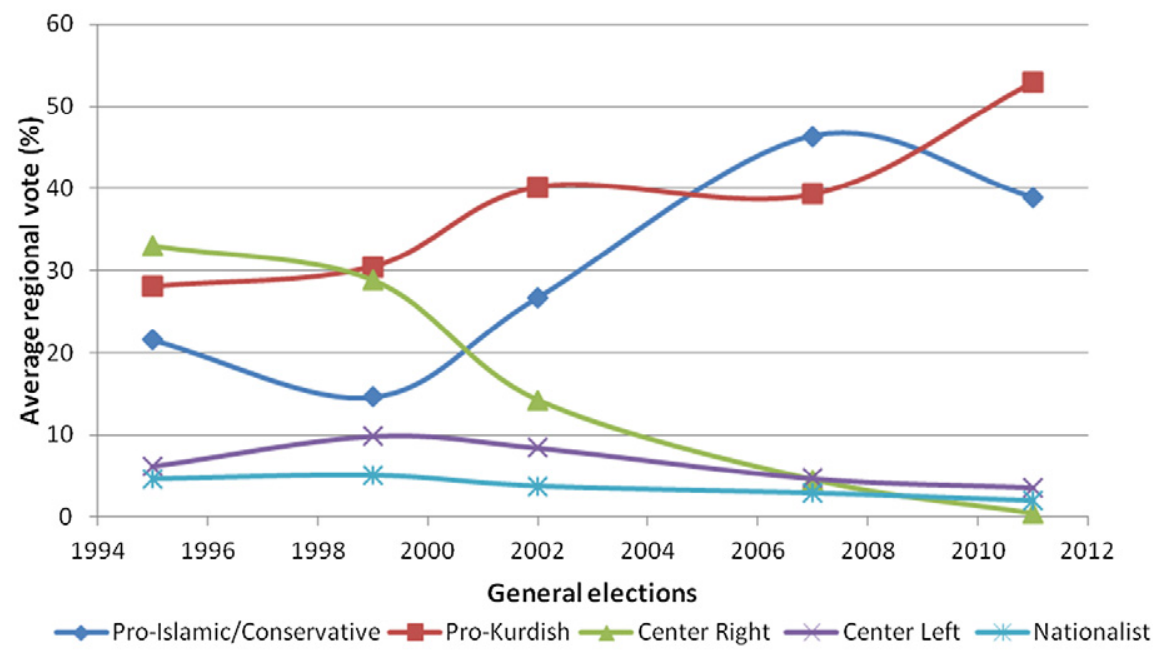

Figure 1. Electoral popularity of major political parties in the Kurdish provinces (1995-2011). Notes: Pro-Islamic and Conservative: RP/FP/SP, AKP; Pro-Kurdish: HADEP/DEHAP/DTP/BDP/Indep.; Center Right: ANAP, DYP, DP; Center Left: CHP, DSP; Nationalist: MHP. Kurdish provinces: Batman, Bitlis, Diyarbakir, Hakkari, Mardin, Mus, Siirt, Sanliurfa, Sirnak, Van. Data Source: TÜIK (http:// www.tuik.gov.tr/).

the centre-left and Turkish nationalist parties have received limited support in the region. The figure also shows that in the 1990s, conservative, centre-right and pro-Kurdish parties were the most popular political parties among Kurds. Strikingly, however, beginning in the 2000s, the centre-right parties have almost vanished from the region. Instead, the conservative AKP, which was established in August 2001, has emerged as the main competitor against ethnic parties in the southeast; it was the most popular party during the July 2007 general elections..$^{29}$ One can argue that the rise of the AKP in the region seems to have forced the secular, pro-Kurdish parties to adopt a new political strategy: a more positive approach toward Islam and the deployment of Islamic ideas and references in Kurdish ethno-politics. Thus, the BDP's increasing pro-Islamic discourse and actions can be interpreted as a challenge to the AKP's monopoly over religion in the region.

\section{Conservative government's response}

The ruling conservative AKP regards Islam as 'cement' between Kurds and Turks. They believe that emphasizing common Islamic ties and the notion of the Islamic brotherhood will constrain Kurdish ethno-nationalism and separatism (see also Yavuz and Ozcan 2006: 103, 112). For example, during his visit to Diyarbakir just before the June 2011 elections, Prime Minister Erdogan criticized Kurdish ethno-nationalism and emphasized Islamic brotherhood and unity: 
We are all the descendants of the great soldiers of great leader Selahaddin Eyyubi [a Kurdish Muslim who established the Ayyubid dynasty] who conquered Palestine and Jerusalem . . . I am against both Turkish and Kurdish nationalisms. All the Kurds and Turks are my brothers ... We turn our faces towards the same qibla [the Caaba in Mecca, the holiest place of Islam]. ${ }^{30}$

Bekir Bozdag, deputy prime minister responsible for Diyanet, also implied that Islam is incompatible with ethno-nationalism:

If a son of a Muslim husband and wife goes to the mountains and joins the terrorist organization [the PKK] to kill innocent people, it is because our men of religion do not really do their duty. If we could teach people Islam very well and if our officials, imams and Koran instructors do their duty appropriately, no terrorist organization would be able to recruit terrorists among the Muslims ... Thus, if there are still people joining the terrorist organization, it is partly because of the failure of our men of religion. ${ }^{31}$

The underlying assumption in such statements is that a devout Muslim individual would not get involved in ethno-nationalism or terrorism. A corollary to that assumption is that the promotion of Islam in society should restrain ethno-nationalist orientations or tendencies.

Probably due to such a perception, the AKP leadership reacted strongly to the BDP's more lenient approach towards religion and increasing usage of Islam in Kurdish ethno-politics. Erdogan asserted that the pro-Kurdish party was exploiting religion to gain votes. To degrade the secular Kurdish movement in the eyes of conservative Kurds, Erdogan claimed that Abdullah Ocalan, imprisoned leader of the PKK, saw himself as God. ${ }^{32}$

Erdogan is particularly disturbed by the Civilian Friday Prayers, condemning them on several occasions: 'They refuse to pray behind the imams appointed by the state. But they are not really religious. We know that they see Apo [Abdullah Ocalan] as a prophet. Thus, they are trying to deceive you' ${ }^{33}$ On another occasion, he maintained his criticisms by stating:

Now, they organize alternative Friday Prayers. But they do not really respect our sacred values. For instance, we see females among those who participate in their Friday Prayers. They also consider Apo as a Prophet. These also show that they do not have anything to do with Islam. Actually they still follow Marxist-Leninist understandings. ${ }^{34}$

He also argued that organizing alternative Friday prayers constitutes a threat to the unity and integrity of religion and the religious community, having a divisive and disruptive impact (nifak, fitne) on Islam. ${ }^{35}$ Erdogan believes that the secular PKK and BDP have nothing to do with Islam; he has claimed that they actually believe in Zoroastrianism (also known as Mazdaism). ${ }^{36}$

Erdogan continued his assaults on the BDP's usage of Islam in politics even after the June 2011 elections. For instance, he reacted harshly to the BDP's headscarf initiative, stating:

Last week, a group in parliament [the BDP] proposed a bill related to headscarves. However, they do not have such a problem. How can those who believe in Zoroastrianism have such a problem or need? Actually, they are just using headscarves for political reasons. ${ }^{37}$ 
During his April 2012 address to the General Council of Independent Industrialists and Businessmen's Association (Müstakil Sanayici ve İ̧sadamlar Derneği, MUSIAD), a conservative business organization, Erdogan criticized Civilian Friday Prayers once again and emphasized the Islamic brotherhood and unity. ${ }^{38}$ In a similar fashion, Idris Naim Sahin, minister for internal affairs, claimed during his address to parliament that the separatist PKK has been forcing its members to consume pork. ${ }^{39} \mathrm{He}$ further claimed that Kurdish ethno-nationalists consider Abdullah Ocalan as a prophet and try to promote Zoroastrianism among the Kurds. ${ }^{40}$

As the previous statements suggest, the conservative AKP employs religious discourse and ideas to discredit Kurdish ethno-nationalism. However, such efforts seem to be paradoxical because as the AKP utilizes Islamic ideas to delegitimize Kurdish ethno-nationalism, it sides with Turkish nationalism. We believe that such an ambivalent attitude deserves a separate research.

A puzzling question remains: If the AKP positioned itself against Kurdish ethno-nationalism and adopted a statist and Turkish nationalist discourse, why is the party still so popular among Kurds? As Figure 1 confirms, despite declining popularity, the AKP is still the second most popular party in the southeast. Some scholars argue that the conservative and anti-systemic identity of the AKP is appealing for religious Kurds (e.g. see Yavuz and Ozcan 2006). The findings of our research, however, suggest that the situation is more complicated. As shown in Table 1, the AKP is more popular among Kurds subscribing to the Hanefi school. In other words, the more religious Shafi Kurds are less likely to vote for the AKP.$^{41}$ Why? Historically, Hanefi Kurds have been closer to urban centers and state authority, while Shafi Kurds have been rural and peripheral. Hanefi Kurds have thus been integrated into the political system more than Shafi Kurds and are thus more likely to support the AKP; Shafi Kurds are more likely to vote for a pro-Kurdish party.

\section{Diyanet's response}

Diyanet, which is Turkey's highest religious public body and deals with religious issues and services and controls religious institutions, ${ }^{42}$ also struggles to respond to religious demands by Kurdish ethno-nationalists. For instance,

Table 1. Contingency table of Kurds' religious sect and voting preferences

\begin{tabular}{|c|c|c|c|c|c|c|}
\hline \multirow{2}{*}{$\begin{array}{l}\text { Voting } \\
\text { preference }\end{array}$} & \multicolumn{5}{|c|}{ Religious Sect } & \multirow[b]{2}{*}{ Total $(\%)$} \\
\hline & Hanefi (\%) & Shafi $(\%)$ & Alevi $(\%)$ & Shia $(\%)$ & Other $(\%)$ & \\
\hline Other & $146(44.8)$ & $374(76.2)$ & $26(96.3)$ & $1(100)$ & $13(100)$ & $560(65.3)$ \\
\hline AKP & $180(55.2)$ & $117(23.8)$ & $1(3.7)$ & $0(0)$ & $0(0)$ & $298(34.7)$ \\
\hline Total & $326(100)$ & $491(100)$ & $27(100)$ & $1(100)$ & $13(100)$ & $858(100)$ \\
\hline \multicolumn{6}{|c|}{$\chi^{2}: 105.000 ;$ df: $4 ; p<0.000$} & \\
\hline
\end{tabular}


facing increasing requests for sermons in Kurdish, Diyanet had to allow the use of Kurdish by state imams in some mosques. Although granting this concession, Diyanet denounced the BDP-supported Civilian Friday Prayers. Prof. Kamil Yilmaz of Diyanet stated to the authors:

We do not have an official position on this matter. However, in order to organize Friday Prayers in a city, one should get permission from the highest religious authority in that area. Otherwise, it would be inappropriate. Besides, we do not like divisions in religion ... We are also definitely against Kurdish ezan [the call for prayer]. It should be in Arabic. ${ }^{43}$

In addition to criticizing Civilian Friday Prayers, Diyanet attempted to formulate some countermeasures. Encouraged by the AKP government, it initiated a project targeting meles in the southeast in December 2011. The project offered about 1,000 meles six months of official religious training and education, after which they would be appointed as official imams and sent back to the mosques in the region..$^{44}$ As this project began after the initiation of the Civilian Friday Prayers, it is believed that it was politically motivated. By employing meles in the public sector, the conservative government wants to prevent cooperation between meles and ethno-nationalists. ${ }^{45}$ Indeed, many meles are skeptical of Diyanet's intentions. For example, Mele Zahit Çiftkuran from DIAYDER feels that the project is designed by the Chief of General Staff and motivated by security concerns. Çiftkuran claims that state officials unfortunately believe that some meles are involved in terrorism. By identifying unofficial imams and employing them within Diyanet, the state and the government want to enhance their control and authority in the region. ${ }^{46}$

\section{Conclusions and implications}

In the last few decades, certain Islamic Kurds have paid increasing attention to the Kurdish problem. It is striking that their discourses on and attitudes toward the Kurdish issue look very similar to the conventional ethnonationalist position. Even more striking, the Kurdish ethno-nationalist movement, which is rooted in secularism and Marxism, has adopted a more lenient approach toward Islam. Put differently, apparently to achieve political and strategic gains against rising conservative actors in the region (i.e. the AKP and religious orders, in particular the pro-Turkish Gulen movement), a secular ethno-political movement is flying ethno-religious colors.

It is noteworthy that we see a common element in the political discourses of Islamist Kurds, secular Kurdish ethno-nationalists, and Turkish-Islamic circles: references to Islam and the Koran. These groups, however, differ in their motivations: Islamist Kurds and secular Kurdish ethno-nationalists utilize Islamic ideas to emphasize 'diversity', 'difference' and 'injustice', while pro-Turkish conservative circles and some Islamists refer to Islam to highlight 'unity', 'oneness' and 'sameness'. In the end, competing Turkish and Kurdish nationalists both instrumentalize religion to legitimize their political messages 
and positions, while trying to delegitimize their opponents. Looking at the past trajectory of Turkish nationalism, we see that it has been close to Islam, particularly since the early 1970s. Using the words of Yavuz (2001: 5-6), 'Islam has always played an important role in the vernacularization of Turkish nationalism, and the nationalists, in turn, redefined Islam as an integral part of national-identity. Turkish nationalism is essentially based on the cosmology of Islam and its conception of community' (see also Cagaptay 2006; Cetinsaya 1999; Taspinar 2005). But the employment of a pro-Islamic discourse by the secular, leftist Kurdish ethno-political movement is a rather interesting development. Whether this is a short-term political strategy to enhance electoral popularity among Kurds or a long-term ideational change remains to be seen. It is, however, clear that after acknowledging and addressing Kurds' Islamic sentiments, the secular, leftist Kurdish movement cannot turn its back on religion again.

What are the policy and theory implications of this intriguing case? One implication is related to the nexus between Islam and ethno-nationalism. As discussed by Sakallioglu (1998: 79), many Islamist writers believe that demolition of the common bond of Islamic brotherhood between Turks and Kurds by the modernization and secularization policies of the early Republic facilitated the rise of Kurdish ethno-nationalism. Such scholars therefore believe that promoting Islam as a shared value among Kurds and Turks would curb or constrain ethno-nationalist ideas and movements. As Houston (1999: 91) also observes 'for Islamist discourse ... kardeşlik [Muslim brotherhood] implies the cessation of separatist claims in the name of Muslim unity . . . and the subordination of Kurdishness to a "higher identity" (üst kimlik)'. For instance, commenting on the role of the pro-Islamic and pro-Turkish Gulen movement in the Kurdish issue, columnist Ali H. Aslan of Today's Zaman, a daily newspaper in sympathy with the movement, states that '[a]dherence to Islam usually softens ethnic conflicts'. ${ }^{47}$

Although many Islamist circles consider Islam as disharmonious with ethno-nationalism, as discussed previously, Kurdish Islamists in Turkey have developed an increasingly ethno-nationalist discourse and attitude in the last decades. Even more interestingly, secular Kurdish ethno-nationalists rooted in Marxist ideology have recently incorporated religion into their ideational toolbox. Thus, Turkish and Kurdish elites are resorting to religion and religious ideas to justify and legitimize their competing nationalist messages. As Smith (2003: 254-61) also argues, as 'sacred foundations and cultural resources', religious motifs, symbols, and ideas might constitute 'basic cultural and ideological building blocks for nationalists'. Similarly, Brubaker (2012: 16) observes that:

... nationalism and religion are often deeply intertwined; political actors may make claims both in the name of the nation and in the name of God. Nationalist politics can accommodate the claims of religion and nationalist rhetoric often deploys religious language, imagery, and symbolism; similarly, religion can accommodate the claims of the nation-state, and religious movements can deploy nationalist language. 
If so, rather than constraining ethno-nationalist orientation or generating mutual understanding and rapprochement between Turkish and Kurdish nationalisms, religion functions as an ideational asset or resource to be utilized by competing nationalists. This implies that the promotion of Islam as a common tie between Kurds and Turks would not necessarily curb or confine Kurdish ethno-nationalism.

The case also has some theoretical implications for the elite analysis. In studies of ethno-nationalism, the elite perspective does not treat ethnic identity as something fixed or given but as instrumentally invented or constructed by political elites (or ethnic entrepreneurs) motivated by certain ideational and/or material interests. Thus, this approach draws attention to the role of elite interaction and the struggle for power in ethno-nationalist processes. Brass (1991: 8), for instance, states:

... ethnicity and nationalism are not 'givens', but are social and political constructions. They are creations of elites, who draw upon, distort, and sometimes fabricate materials from the cultures of the groups they wish to represent in order to protect their wellbeing or existence or to gain political and economic advantage for their groups as well as for themselves.

Likewise, Lecours (2000) draws attention to the role of political elites and institutions in ethno-nationalism. Treating ethno-nationalism as a top-down, political process, he identifies three main stages in an ethno-nationalist movement: (1) creation, transformation and crystallization of ethnic identities; (2) interest definition; and (3) politicization and mobilization of ethnic identities. It is argued that as ethnic entrepreneurs, political elites play significant roles in all those stages. Elites are 'not only active in nationalist mobilization but also in the construction, transformation and politicization of ethnic identities, and in the definition of an ethnic group's interests' (Lecours 2000: 118; see also Haymes 1997). Thus, from the elite perspective, political elites construct, frame or manipulate ethnic symbols, myths or ideas to legitimize their ethnonationalist positions and to compete against elites from other camps.

The elite perspective faces some valid criticisms, especially by primordialists. It is argued that it ignores the cultural and historical roots of ethnic identity. McGarry (1995: 134), for instance, states:

[the elite perspective] assumes that ethnonational divisions are superficial, without deep roots. There is no doubt that elites play an important role in mobilizing nationalist movements of course, though these movements cannot be mobilized out of thin air and require some basis in society and history (a different language for example).

This study does not really take sides with modernist or primordialist approaches on ethnicity and nationalism. Nevertheless, by drawing attention to the role of political elites in ethnic mobilization, elite theory does contribute to our comprehension of ethno-nationalism. Kurdish leaders have played substantial roles in promoting the Kurdish cause in the Turkish Republic. Kurdish elites have been involved in various activities of identity construction, interest definition and politicization and mobilization of Kurdish ethnic 
identity (see also Watts 2006). Influenced by Marxism in the pre-1990 period, Kurdish political elites and intellectuals approached the Kurdish issue from class perspective. In the aftermath of the end of the Cold War, however, the Marxist influence on Kurdish movement declined. As a result, the Kurdish elites underscored human rights and freedoms and democracy as their guiding principles in the 1990s. Regarding religion, the Kurdish ethno-nationalist discourse either ignored or relegated Islam to a secondary position. Recently, however, secular Kurdish ethno-nationalists have paid greater attention to Kurds' religious sentiments and rights. By incorporating Islam and Islamic sentiments into their political discourse and strategies, secular Kurdish ethnonationalists have consciously or unconsciously reconstructed 'Kurdishness'. Thus, the discovery of Islam by secular Kurdish political elites in the last decade corresponds to a new stage in Kurdish identity construction.

There is, however, a limit to such efforts. Motivated by the desire to enhance their popular appeal and to counter state accusations that they are Marxist atheists or Zoroastrianists, Kurdish elites have incorporated Sunni Islamic understandings and ideas into their political discourse and actions. Such an initiative, however, is likely to alienate non-Sunni Kurds (e.g. Alevis), which is why Kurdish political elites occasionally state that they welcome all believers. ${ }^{48}$ Such remarks imply that the heterogeneity of Kurdish society has a constraining impact on ethnic entrepreneurs' constructions of ethnic identity and ethnic mobilization.

In sum, elite constructions and deconstructions of ethnicity or ethnic identity matter in ethno-nationalism, but such interpretations do not take place in a vacuum. Diachronic and synchronic factors and dynamics (i.e. historical, social, political and economic factors and developments) condition ethnic entrepreneurs' discourses and strategies. This view suggests that a better comprehension of the evolution of the Kurdish issue requires us to pay attention not only to elite preferences and actions but also to the structural constraints under which ethnic agents or entrepreneurs operate.

\section{Acknowledgements}

An earlier version of this study was presented at the 70th Annual Midwest Political Science Association Conference, 12-15 April 2012, Chicago, IL, USA. The authors would like to thank Ilker Ayturk, Fatih Durgun, Sarah Fischer, Michael M. Gunter, Christopher Houston, Ahmet Kuru, Rana Nelson, Kerem Oktem, Elisabeth Ozdalga, Cenk Saracoglu and Binnaz Toprak for their very useful comments and suggestions.

\section{Appendix: the list of interviewees}

1. Abdullah Demirbaş, BDP Sur Mayor, 24 May 2011 and 18 February 2012, Diyarbakir. 
2. Abdürrühim Ay, Mazlum-Der, 24 May 2011, Diyarbakir.

3. Adnan Firat, Rewşen, 29 July 2011, Ankara.

4. Ahmet Aday, chairperson of Kürt-Der, 19 August 2011, Ankara.

5. Ahmet Erkol, Assoc Prof Dr, Dicle University, Faculty of Divinity, 19 February 2012, Diyarbakir.

6. Ahmet Faruk Ünsal, chairperson of Mazlum-Der, 28 June 2011, 27 December 2011, Ankara.

7. Ali Serdar Tuncer, chairperson of Gönül Köprüsü Derneği, 17 February 2012, Diyarbakir.

8. Altan Tan, BDP deputy, 23 May 2011, Diyarbakir.

9. Arjin Ari, Kürt-Pen, Kurdish poet, writer, 18 February 2012, Diyarbakir.

10. Ayhan Bilgen, BDP party assembly, 13 July 2011, Ankara.

11. Aziz İstegün, Zaman Daily, 17 February 2012, Diyarbakir.

12. Bayram Bozyel, chairperson of $H A K-P A R, 7$ August 2011, Ankara.

13. Bilal Zilan, Dil-Der, Zazaki, 24 May 2011, Diyarbakir.

14. Cevat Öneş, retired member of the National Intelligence Organization (Milli İstihbarat Teşikaltı), 22 August 2011, Ankara.

15. Ferzande Lale, Ayder, 24 May 2011, Diyarbakir.

16. Gülten Kişanak, co-leader of the BDP, 26 February 2012, Ankara.

17. Hüseyin Y1lmaz, chairperson of Mustazaf-Der, 19 February 2012, Diyarbakir.

18. İbrahim Y1lmaz, retired imam, member of AKP Diyarbakir-Bağlar party assembly, 17 February 2012, Diyarbakir.

19. Kamil Yilmaz, Prof Dr, Diyanet, 15 September 2011, Ankara.

20. Kawa Nemir, Türkiye PEN, 22 May 2011, Diyarbakir.

21. Kemal Burkay, $H A K-P A R, 4$ May 2012, Ankara.

22. Mahmut Bozarslan, NTV, 23 May 2011, Diyarbakir; El Cezire, 18 February 2012, Diyarbakir.

23. Mehmet Aslan, chairperson of Diyarbakir Chamber of Trade and Industry, 23 May 2011, Diyarbakir.

24. Mehmet Emin Aktar, chairperson of Diyarbakir Bar, 23 May 2011, Diyarbakir.

25. Mehmet Gönden (Kawari), mele, member of the BDP Diyarbakir party assembly, 18 February 2012, Diyarbakir.

26. Meral Danış Bektaş, lawyer, assistant to BDP co-leader, 18 February 2012 , Diyarbakir.

27. Muhammed Akar, lawyer, descendant of Sheikh Said, 21 May 2011, 17 February 2012, Diyarbakir.

28. Muhittin Batmanl, Dicle-Frrat Diyalog Grubu (Tigris-Euphrates Dialogue Group), 23 May 2011, Diyarbakir.

29. Muhittin Kaya, Nübihar, Zehra, 6 August 2011, Ankara.

30. Mustafa Kamalak, leader of the Felicity Party (SP), 13 March 2012.

31. Nuri Güler, Mustazaf-Der, 24 May 2011, Diyarbakir.

32. Öztürk Türkdoğan, chairperson of Insan Hakları Derneği, 12 July 2011, Ankara. 


\section{Recep İdikut, IHH Insani Yardım Derneği (IHH Association for Humani- tarian Aid), 23 May 2011, Diyarbakir.}

34. Sedat Yurttaş, former DEP deputy, 17 February 2012, Diyarbakir.

35. Selahattin Çoban, Zehra Group, 24 May 2011, Diyarbakir.

36. Serdar Bülent Y1lmaz, Özgür-Der, 23 May 2011, Diyarbakir.

37. Seydi Firat, Barış Meclisi (Peace Assembly), former PKK member, 13 September 2011, Ankara.

38. Vahap Coşkun, Assoc Prof Dr, Dicle University, Law Faculty, 21 January 2012, Ankara.

39. Zahit Çiftkuran, mele, chairperson of DIA YDER (close to the BDP), 18 February 2012, Diyarbakir.

\section{Notes}

1 For some notable exceptions, see Atacan 2001, Bruinessen 1992, 2000, Duran 1998, Houston 2001, Sakallioglu 1998, Sarigil 2010 and Yavuz and Ozcan 2006.

2 We conducted 39 interviews with politicians, local administrators, intellectuals, activists and representatives of civil-society organizations from pro-Islamic and secular camps in Ankara (Turkey's capital) and Diyarbakir (the largest city in the southeast). We asked questions about participants' opinions on the nature and source of the problem, possible solutions, the government's Kurdish initiative, the role of religion, the results of the June 2011 general elections and the resumed armed conflict between security forces and the PKK. Please see the appendix for the list of interviewees.

3 In conjunction with the respected public opinion research company A\&G based in Istanbul, we conducted a public opinion survey in late November 2011 with a nationwide, representative sample of 6,500 individuals from 48 provinces. The survey, which was part of a separate research project, aimed at identifying Kurdish ethno-political demands and explaining causal factors and dynamics behind Kurdish ethno-nationalism in Turkey.

4 The contemporary Islamist approach to the Kurdish issue shares some similarities with the ideology of pan-Islamism, promoted by Abdulhamid II (1842-1918), who reigned between 1876 and 1909. To prevent further disintegration of the Ottoman Empire and keep Ottoman Muslim elements together, Abdulhamid II tried to use the legitimacy of the Caliphate (see Cetinsaya 1999: 352).

5 Previous National Outlook Movement parties included the National Order Party (Milli Nizam Partisi, 1970-1971), the National Salvation Party (Milli Selamet Partisi, 1972-1980), the Welfare Party (Refah Partisi, RP, 1983-1998) and the Virtue Party (Fazilet Partisi, FP, 1997-2001). These parties were accused of constituting a major threat to the secular nature of the Republic and were closed down either by military regimes or the Constitutional Court.

6 Authors' interview, 13 March 2012, Ankara.

7 Authors' interview, 23 May 2011, Diyarbakir.

8 Authors' interview, 19 February 2012, Diyarbakir.

9 As a Kurdish ethno-nationalist party, the BDP was established in 2008 as a successor to the pro-Kurdish Democratic Society Party (Demokratik Toplum Partisi, DTP), which was accused of acting against the indivisible unity of the state's people and its territory and of involvement in separatism and was thus banned by the Constitutional Court. In the last general elections (June 2011), the BDP supported independent candidates. Currently, it is represented with 36 deputies in parliament, the highest parliamentary representation achieved by a Kurdish party in the history of Turkey's Kurdish movement. 
10 See 'Dindar Kurtlerin partisi geliyor', Radikal, 30 April 2012, available at: http://www. radikal.com.tr/Radikal.aspx?aType=RadikalDetayV3\&ArticleID=1086570\&CategoryID=77 (accessed 30 April 2012).

11 The Zehra Group presents itself as a follower of the teachings and writings of Said-i Nursi (1878-1960), a Kurdish Islamic scholar from Turkey. The group emphasizes Nursi's Kurdish origins, referring to him as Said-i Kurdi (the Kurdish Said). The group published the first Kurdish translation of Nursi's Risale-i Nur (Treatise on the Divine Light).

12 On the attitude of the Gulen community toward the state, Turkish nationalism and Kurdish nationalism, see Houston 2001: 147-55.

13 Authors' interview, 6 August 2011, Ankara.

14 Selahattin Coban of the Zehra Group made similar observations (authors' interview, 23 May 2011, Diyarbakir).

15 The disintegration of the communist bloc played a substantial role in this ideological shift.

16 The PKK leadership was probably trying to counter the government's efforts to present the PKK as an atheist organization (see also Bruinessen 2000: 56; McDowall 1996: 433-34).

17 Quoted in 'BDP going after the religious vote', Turkish Politics in Action, 7 April 2011, available at http://www.turkishpoliticsinaction.com/2011/04/bdp-going-after-religious-vote.html (accessed 14 March 2012).

18 Madrasas were officially banned in May 1924 as part of the secularization reforms in the newly established Republic. However, many of them continued to operate informally and secretly, especially in the Kurdish southeast. Besides Arabic and Persian, Kurdish is also taught at these madrasas. It is believed that madrasas have contributed to the evolution of Kurdish nationalidentity and consciousness among the Kurds (see Bruinessen 2000: 37, 48).

19 Meles have divided loyalties as well. According to Ibrahim Yilmaz, a retired state imam living in Diyarbakir, some identify with the Kurdish ethno-nationalist movement (i.e. the BDP), and meles from this group conduct the Civilian Friday Prayers. Another group identifies with the ruling, conservative AKP. The third group claims no affiliation with either the ethnic party or the conservative party. Meles who distance themselves from the ethnic party are more critical of Civilian Friday Prayers (authors' interview, 17 February 2012, Diyarbakir).

20 Quoted in 'Thousands joined Civil Friday Prayer', Firat News Agency, 6 May 2011, available at http://en.firatnews.com/index.php?rupel=article\&nuceID=2138 (accessed 13 March 2012).

21 See 'Seyh Sait'e asildigi yerde anma', Dogan Haber Ajansi, 29 June 2011, available at http:// www.dha.com.tr/haberdetay.asp?Newsid=179801 (accessed 16 March 2012).

22 'Başbakan'a şeriat cağrısı', Güncel (a local daily published in Diyarbakir), 19 February 2012, p. 7.

23 It was also proposed that the requirement of wearing a tie for male parliamentarians should be removed. See 'BDP'den turban ve kravat onergesi', Sabah, 12 October 2011, available at http:// www.sabah.com.tr/Gundem/2011/10/12/bdpden-turban-ve-kravat-onergesi (accessed 14 March 2011).

24 See 'The Koran', translated by Arthur J. Arberry (Oxford: Oxford University Press, 1990).

25 DIAYDER, based in Diyarbakir, was established in July 2007 by active and retired meles and some retired sate imams. Currently, it has 186 members. As an association close to the Kurdish political movement, DIAYDER employs Islamic ideas and arguments in its efforts to promote Kurdish cultural and political rights.

26 Authors' interview, 18 February 2012, Diyarbakir.

27 Authors' interview, 18 February 2012, Diyarbakir.

28 Authors' interview, 26 February 2012, Ankara.

29 This was primarily because of the pro-reform agenda pursued by the AKP in its first term in office (2002-2007); its positive approach toward the Kurds and Kurdish demands in the same period, economic stability and societal reaction to the military's failed attempt to prevent the ascendance of Foreign Minister Abdullah Gul, AKP candidate, to the presidency in Spring 2007.

(C) The author(s) 2013. Nations and Nationalism (C) ASEN/John Wiley \& Sons Ltd 2013 
30 'Inkar da bitti, asimilasyon da', Radikal, 2 June 2011, available at http://www.radikal. com.tr/Radikal.aspx?aType $=$ RadikalDetayV3\&ArticleID=1051453\&CategoryID=78 (accessed 15 March 2012).

31 See 'Din adamlarimizin hatasi var', Haber Turk, 21 January 2012, available at http:/l www.haberturk.com/gundem/haber/708246-din-adamlarimizin-hatasi-var. (accessed 22 March 2012).

32 See 'Turkish PM slams pro-Kurdish BDP in Bingol', Hurriyet Daily News, 8 June 2011, available at http://www.hurriyetdailynews.com/default.aspx?pageid=438\&n=pm-slams-bdp-inbingol-2011-06-08 (accessed 13 March 2012).

33 Quoted by Dorian Jones in 'Turkey: Kurds boycott mosques for language rights', Eurasianet, 7 June 2011, available at http://www.eurasianet.org/node/63639 (accessed 13 March 2012).

34 'Erdogan'dan dindar Kurtlere cok agir ifadeler', Firat News Agency, 10 May 2011, available at http://www.firatnews.com/index.php?rupel=nuce\&nuceID=42608 (accessed 15 March 2012).

35 'Apo'yu peygamber ilan ediyorlar', Milliyet, 30 April 2011, available at http:// www.milliyet.com.tr/-apo-yu-peygamber-ilan-ediyorlar-/siyaset/haberdetay/01.05.2011/1384560/ default.htm, (accessed 15 March 2012); 'Basbakan Erdgan ses kaydiyla vurdu', Dogan Haber Ajansi, 1 June 2011, available at http://www.dha.com.tr/haberdetay.asp?Newsid=168014 (accessed: 15 March 2012).

36 'Erdogan: Ramazan'dan sonra cok farkli olacak', Radikal, 15 August 2011, available at http://www.radikal.com.tr/Radikal.aspx?aType=RadikalDetayV3\&CategoryID=78\&ArticleID= 1059975 (accessed 14 March 2012); 'Erdogan: Kurtler Zerdust degil, Islam'dir', Radikal, 18 November 2011, available at http://www.radikal.com.tr/Radikal.aspx?aType=RadikalDetayV3\& ArticleID=1069962\&CategoryID=78, (accessed 14 March 2012).

37 'Dini Zerdustluk olanin boyle bir derdi olabilir mi?' Milliyet, 15 October 2011, available at http://siyaset.milliyet.com.tr/-dini-zerdustluk-olanin-boyle-bir-derdi-olabilir-mi-/siyaset/

siyasetdetay/15.10.2011/1451167/default.htm. (accessed 14 March 2012).

38 See 'Erdogan MUSIAD genel kurulunda konustu', Hurriyet, 28 April 2012, available at http:// www.hurriyet.com.tr/gundem/20441058.asp (accessed 30 April 2012).

39 Islam forbids the consumption of pork.

40 'Meclis'te domuz kavgasi', NTV, 17 April 2012, available at http://www.ntvmsnbc.com/id/ 25341088 (accessed 18 April 2012).

41 The majority of Sunni Kurds in Turkey (around sixty per cent) adhere to the Shafi school (mezhep), one of the four major schools of Sunni Islamic jurisprudence. The vast majority of Sunni Turks (around ninety per cent), however, subscribe to Hanefi school, which was the official school of the Ottoman Empire.

42 Diyanet, a state institution that oversees religion, was established in 1924, and controls nearly 80,000 mosques in Turkey. Because Diyanet is based on Hanefi-Sunni Islam (see Smith 2005), it is criticized particularly by Alevi Turks and Kurds and Shafi Kurds.

43 Authors' interview, 15 September 2011, Ankara.

44 See 'Mele acilimi bir Diyanet projesi', Star, 19 December 2011, available at http:// www.stargazete.com/politika/-mele-acilimi-bir-diyanet-projesi-haber-407067.htm (accessed 15 March 2011).

45 Authors interview with Sedat Yurttas, former DEP deputy, 17 February 2012, Diyarbakir. See also Vahap Coskun, 'Meleler ve devlet', Radikal 2, 18 December 2011, available at http:// www.radikal.com.tr/Radikal.aspx?aType=HaberYazdir\&ArticleID=1073011 (accessed 24 March 2012).

46 Authors interview, 18 February 2012, Diyarbakir. Mele Mehmet Gonden (Kawari) also questioned the intentions of the project.

47 Ali H. Aslan, 'Does the Gulen movement securitize the Kurdish question?' Today's Zaman, 2 March 2012.

48 For instance, authors' interview with BDP co-leader Gulten Kisanak. 


\section{References}

Atacan, F. 2001. 'A Kurdish Islamist group in modern Turkey: shifting identities', Middle Eastern Studies 37, 3: 111-44.

Ataman, M. 2003. 'Islamic perspective on ethnicity and nationalism: diversity or uniformity?' Journal of Muslim Minority Affairs 23, 1: 89-102.

Brass, P. 1991. Ethnicity and Nationalism: Theory and Comparison. New Delhi; Newbury Park, CA; London: Sage Publications.

Brubaker, R. 2012. 'Religion and nationalism: four approaches', Nations and Nationalism 18, 1: $2-20$.

Bruinessen, M. V. 1992. Agha, Shaikh and State: The Social and Political Structures of Kurdistan. London; Atlantic Highlands, NJ: Zed Books.

Bruinessen, M. V. 2000. Mullahs, Sufis and Heretics: The Role of Religion in Kurdish Society: Collected Articles. Istanbul: Isis Press.

Cagaptay, S. 2006. Islam, Secularism, and Nationalism in Modern Turkey: Who Is a Turk?. New York: Routledge.

Cetinsaya, G. 1999. 'Rethinking nationalism and Islam: some preliminary notes on the roots of 'Turkish-Islamic synthesis' in modern Turkish political thought', The Muslim World 89, 3-4: 350-76.

Duran, B. 1998. "Approaching the Kurdish question via "Adil Duzen": an Islamist formula of the welfare party for ethnic coexistence', Journal of Muslim Minority Affairs 18, 1: 11129.

Entessar, N. 1992. Kurdish Ethnonationalism. Boulder, CO; London: Lynne Rienner Publishers.

Haymes, T. 1997. 'What is nationalism really? Understanding the limitations of rigid theories in dealing with the problems of nationalism and ethnonationalism', Nations and Nationalism 3, 3: 541-57.

Houston, C. 1999. 'Civilizing Islam, Islamist civilizing? Turkey's Islamist movements and the problem of ethnic difference', Thesis Eleven 58, 1: 83-98.

Houston, C. 2001. Islam, Kurds and the Turkish Nation State. Oxford; New York: Berg.

Jongerden, J. and Akkaya, H. A. 2011. 'Born from the left: the making of the PKK' in M. Casier, J. Jongerden (eds.), Nationalisms and Politics in Turkey: Political Islam, Kemalism and the Kurdish Issue. New York: Routledge, 123-42.

Jwaideh, W. 2006. Kurdish National Movement: Its Origins and Development. New York: Syracuse University Press.

Lecours, A. 2000. 'Ethnonationalism in the West: a theoretical exploration', Nationalism \& Ethnic Politics 6, 1: 103-24.

McDowall, D. 1992. The Kurds: A Nation Denied. London: Minority Rights Publication.

McDowall, D. 1996. A Modern History of the Kurds. London: I.B. Tauris.

McGarry, J. 1995. 'Explaining ethnonationalism: the flaws in Western thinking', Nationalism \& Ethnic Politics 1, 4: 121-42.

Ozcan, N. A. 1999. PKK (Kurdistan Isci Partisi) Tarihi, Ideolojisi Ve Yontemi. Ankara: ASAM.

Sakallioglu, U. C. 1998. 'Kurdish nationalism from an Islamist perspective: the discourse of Turkish Islamist writers', Journal of Muslim Minority Affairs 18, 1: 73-89.

Sarigil, Z. 2010. 'Curbing Kurdish ethnonationalism in Turkey: an empirical assessment of pro-Islamic and socio-economic approaches', Ethnic and Racial Studies 33, 3: 533-53.

Smith, A. D. 2003. Chosen Peoples: Sacred Sources of National Identity. Oxford: Oxford University Press.

Smith, T. W. 2005. 'Civic nationalism and ethnocultural justice in Turkey', Human Rights Quarterly 27, 2: 436-70.

Taspinar, O. 2005. Kurdish Nationalism and Political Islam in Turkey. New York: Routledge.

Vatikiotis, P. J. 1987. Islam and the State. New York: Routledge.

Watts, N. F. 2006. 'Activists in office: pro-Kurdish contentious politics in Turkey', Ethopolitics 5, 2: $125-44$.

(C) The author(s) 2013. Nations and Nationalism (C) ASEN/John Wiley \& Sons Ltd 2013 
White, P. 2000. Primitive Rebels or Revolutionary Modernizers? The Kurdish National Movement in Turkey. London: Zed Books.

Yavuz, M. H. 1997. 'Political Islam and the Welfare (Refah) Party in Turkey', Comparative Politics 30, 1: 63-82.

Yavuz, M. H. 2001. 'Five stages of the construction of Kurdish nationalism in Turkey', Nationalism \& Ethnic Politics 7, 3: 1-24.

Yavuz, M. H. and Ozcan, N. A. 2006. 'The Kurdish question and Turkey's justice and development party', Middle East Policy 13, 1: 102-19. 